\title{
COVID-19 and the Differences in Physiological Background Between Children and Adults and Their Clinical Consequences
}

\author{
Lenka KAPUSTOVA ${ }^{1^{*}}$, Otilia PETROVICOVA ${ }^{1^{*}}$, Peter BANOVCIN ${ }^{1}$, Martina \\ ANTOSOVA $^{2}$, Anna BOBCAKOVA ${ }^{3}$, Ingrid URBANCIKOVA ${ }^{5}$, Zuzana RENNEROVA ${ }^{4}$, \\ Miloš JESENAK ${ }^{1,3,6}$ \\ * These authors contributed equally to this work. \\ ${ }^{1}$ Centre for Primary Immunodeficiencies, Clinic of Paediatrics, Jessenius Faculty of Medicine in \\ Martin, Comenius University in Bratislava, University Hospital in Martin, Martin, Slovak Republic, \\ ${ }^{2}$ University Hospital in Martin, Martin, Slovak Republic, ${ }^{3}$ Centre for Primary Immunodeficiencies, \\ Clinic of Pneumology and Phthisiology, Jessenius Faculty of Medicine in Martin, Comenius \\ University in Bratislava, University Hospital in Martin, Martin, Slovak Republic, ${ }^{4}$ Clinic of \\ Paediatric Pulmonology and Phthisiology, Faculty of Medicine, Slovak Medical University, \\ National Institute of Children's Diseases, Bratislava, Slovak Republic, ${ }^{5}$ Clinic of Paediatrics, \\ Faculty of Medicine, P.J. Safarik University, Children Faculty Hospital, Kosice, Slovak Republic, \\ ${ }^{6}$ Department of Clinical Immunology and Allergology, University Hospital in Martin, Martin, \\ Slovak Republic
}

Received July 12, 2021

Accepted September 23, 2021

\section{Summary}

The SARS-CoV-2 pandemic has indeed been one of the most significant problems facing the world in the last decade. It has affected (directly or indirectly) the entire population and all age groups. Children have accounted for $1.7 \%$ to $2 \%$ of the diagnosed cases of COVID-19. COVID-19 in children is usually associated with a mild course of the disease and a better survival rate than in adults. In this review, we investigate the different mechanisms which underlie this observation. Generally, we can say that the innate immune response of children is strong because they have a trained immunity, allowing the early control of infection at the site of entry. Suppressed adaptive immunity and a dysfunctional innate immune response is seen in adult patients with severe infections but not in children. This may relate to immunosenescence in the elderly. Another proposed factor is the different receptors for SARS-CoV-2 and their differences in expression between these age groups. In infants and toddlers, effective immune response to viral particles can be modulated by the pre-existing non-specific effect of live attenuated vaccines on innate immunity and vitamin $D$ prophylaxis. However, all the proposed mechanisms require verification in larger cohorts of patients. Our knowledge about SARS-CoV-2 is still developing.

\section{Key words}

COVID-19 • Children • Adults • Age-related differences • Disease severity

\section{Corresponding authors}

Z. Rennerová, Clinic of Pediatric Pneumology and Phthisiology, Faculty of Medicine, Slovak Medical University, National Institute of Children's Diseases, Krajinska 91, 82556 Bratislava, Slovak Republic. E-mail: zuzana.rennerova@nudch.sk and M. Jeseňák, Clinic of Pneumology and Phthisiology, Clinic of Paediatrics, Department of Clinical Immunology and Allergology, Jessenius Faculty of Medicine in Martin, Comenius University in Bratislava, University Teaching Hospital in Martin, Kollarova 2, 03659 Martin, Slovak Republic. E-mail: jesenak@gmail.com

\section{Introduction}

The SARS-CoV-2 pandemic has indeed been 
one of the most significant problems facing the world in the last decade. It has affected (directly or indirectly) the entire population and all age groups. Children have accounted for $1.7 \%$ to $2 \%$ of the diagnosed cases of COVID-19. COVID-19 in children is usually associated with a mild course of the disease and a better survival rate than in adults. In this review, we investigate the different mechanisms which underlie this observation. Generally, we can say that the innate immune response of children is strong because they have a trained immunity, allowing the early control of infection at the site of entry. Suppressed adaptive immunity and a dysfunctional innate immune response is seen in adult patients with severe infections but not in children. This may relate to immunosenescence in the elderly. Another proposed factor is the different receptors for SARS-CoV-2 and their differences in expression between these age groups. In infants and toddlers, effective immune response to viral particles can be modulated by the pre-existing nonspecific effect of live attenuated vaccines on innate immunity and vitamin D prophylaxis. However, all the proposed mechanisms require verification in larger cohorts of patients. Our knowledge about SARS-CoV-2 is still developing.

\section{Differences in pathomechanism between children and adults with COVID-19 infection}

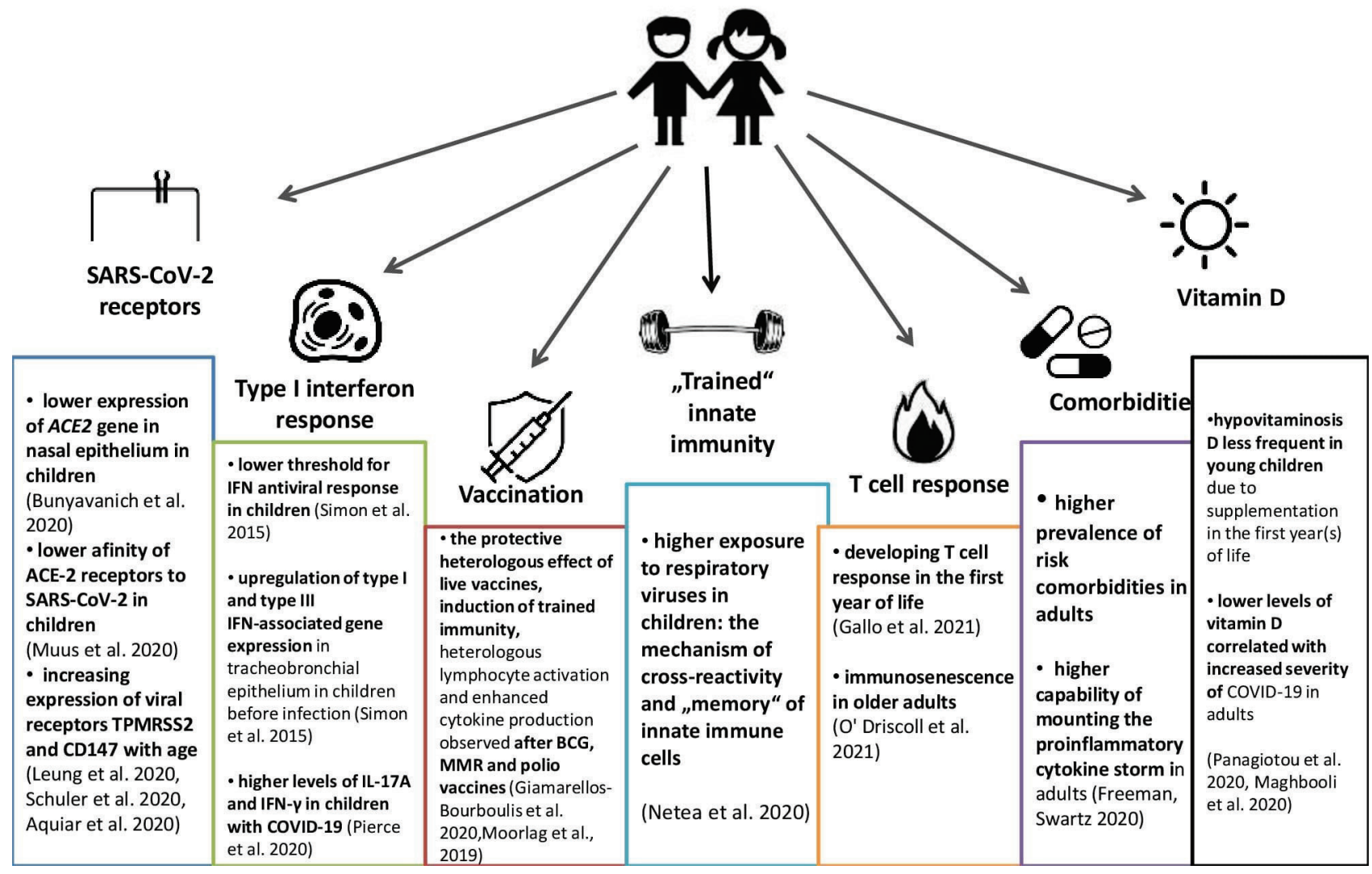

Fig. 1. Main differences in pathomechanism between children and adults with COVID-19 infection.

\section{Introduction}

COVID-19 infection caused by SARS-CoV-2 is one of the main problems in the entire population. It has been more than a year since we have had to modify our lives to fight the virus and stay healthy. Children have accounted for $1.7 \%$ to $2 \%$ of the diagnosed cases of
COVID-19. They often have a milder course of the disease than adults, and child deaths have been rare. The documented risk factors for severe disease in children are very young age and underlying comorbidities (Tsabouri et al. 2021). Identification of the potential risk factors in both adults and children would be of immense value to all healthcare professionals in predicting the severe course of 
the disease (Marin et al. 2021). Severe COVID-19 disease is associated with high and persistent viral loads in adults. A strong innate immune response in children is due to trained immunity, which probably allows early control of infection at the site of entry. Suppressed adaptive immunity and a dysfunctional innate immune response is seen in adult patients with severe infections but not in children. This may relate to immunosenescence in the elderly. Insight into the pathophysiological mechanisms of lower severity in children might be important in devising therapeutics for high-risk adults and the elderly (Dhochak et al. 2020).

\section{Epidemiology}

The novel coronavirus disease is currently the most serious pandemic of the millennium. It has affected over three million of the population in over 185 countries and caused over 220,000 deaths. Around $10 \%$ of hospitalized patients are critical, and mortality in currently known cases is estimated to be 4 to $7 \%$ (Boban et al. 2021). Paediatric mortality ranges from 0.1 to $4 \%$ (Taffarel et al. 2021). The precise causes of severe disease are not known, but it appears that host factors primarily rather than viral genetic mutations drive the pathogenesis (Gallo et al. 2021). Age is a major predictor of mortality, and it is therefore considered a key factor in proposed clinical severity risk scores. The infection fatality ratio has been found to be lowest in children aged 5 to 9 years, with a log-linear increase according to age in individuals older than 30 years. Elderly individuals ( 75 years and over) have a much higher mortality rate (O'Driscoll et al. 2021). Males with the disease are more likely than females to have severe symptoms and require hospitalization. The risk of death if infected with SARSCoV-2 is significantly higher in males than females, particularly in older individuals. Low rates of prepubertal mortality may be due to the different levels of sex hormones (Castagnoli et al. 2020, Sharifi 2020). Androgen levels increase in puberty and are higher in males than females and have been hypothesized as having a role in the severity of COVID-19 in patients (Sharifi et al. 2020, Wambier et al. 2020). Pre-existing comorbidities, such as cardiovascular diseases, chronic kidney disease, chronic obstructive pulmonary disease, diabetes mellitus, hypertension, immunosuppression, obesity, and sickle cell disease predispose patients to an adverse clinical course and increased risk of intubation and death. Cancers, particularly hematological and pulmonary malignancies, are also thought to be a major comorbidity associated with poor outcomes in COVID-19 patients. In children, comorbidities include selected primary immunodeficiencies, syndromological diseases, autism, neurological diseases and autoimmune diseases. These conditions and very young age (less than 1 year) are associated with a more severe course of the disease. Trained immunity is also insufficient in the first year of life (Gallo et al. 2021).

\section{Clinical picture}

The coronavirus disease is spread through human to human transmission, typically through close contact via respiratory droplets produced by sneezing, coughing and even breathing and talking. The initial reproductive number of transmissions is estimated to be from 2.2 to 3.9. The incubation period averages between 3 and 5 days, with an interval range of 2 days to 2 weeks (Boban et al. 2021). The clinical presentation of COVID19 infection can involve multiorgan systems, with mild to moderate and severe symptoms (Table 1) (Machhi et al. 2020). Symptomatic patients typically manifest sore throat, nasal congestion, fever, malaise, dyspnea and cough from 4 to 7 days. Other clinical symptoms include anosmia, ageusia, muscle weakness, tiredness, headache and diarrhea. Viral pneumonia can develop from day 5 to the second or third week, with hypoxemia depending on the clinical severity (Boban et al. 2021). Fever, cough, or shortness of breath were described in $73 \%$ of children and $93 \%$ of adults. Myalgia, sore throat, headache and diarrhea were also less commonly reported by pediatric patients. Children are very often asymptomatic or only have a mild course of the disease. However, children aged less than 1 year accounted for the highest hospitalization rate (Sinaei et al. 2021). The occurrence of severe and critical disease in children was $10.6 \%$ in children aged less than 1 year, $7.3 \%$ aged 1 to 5 years, $4.2 \%$ aged 6 to 10 years, $4.1 \%$ aged 11 to 15 years, and $3 \%$ aged 16 to 17 years (Dong et al. 2020). Some patients experience a severe course of SARS-CoV-2 infection characterized by hyper-proinflammatory response or a cytokine storm, which leads to acute respiratory distress syndrome (ARDS). This is more typical in adults, although multisystem inflammatory syndromes can also occur in children and young adults (MIS-C, MIS-A) (Sinaei et al. 2021). 
Table 1. Clinical presentation of COVID-19 infection.

\begin{tabular}{|c|c|c|c|c|}
\hline \multicolumn{5}{|c|}{ Clinical presentation of COVID-19 infection } \\
\hline $\begin{array}{l}\text { Respiratory } \\
\text { system }\end{array}$ & $\begin{array}{c}\text { Nervous } \\
\text { system }\end{array}$ & $\begin{array}{c}\text { Gastrointestinal } \\
\text { system }\end{array}$ & $\begin{array}{c}\text { Cardiovascular } \\
\text { system }\end{array}$ & $\begin{array}{l}\text { Uropoetic } \\
\text { system }\end{array}$ \\
\hline \multicolumn{5}{|l|}{ Mild disease } \\
\hline $\begin{array}{l}\text { Cough } \\
\text { Sore throat } \\
\text { Rhinorrhea } \\
\text { Sneezing } \\
\text { Dry cough }\end{array}$ & $\begin{array}{c}\text { Hyposmia-anosmia } \\
\text { Hypogeusia-ageusia } \\
\text { Visual disturbance } \\
\text { Fatigue, somnolence } \\
\text { Depressed mood } \\
\text { Anxiety, Insomnia } \\
\text { Anger, Fear }\end{array}$ & $\begin{array}{l}\text { Nausea } \\
\text { Vomiting } \\
\text { Diarrhea }\end{array}$ & $\begin{array}{c}\text { Chest pain } \\
\text { Arrythmia } \\
\text { Sinus tachycardia } \\
\text { Blood coagulation }\end{array}$ & $\begin{array}{l}\text { Proteinuria } \\
\text { Hematuria }\end{array}$ \\
\hline \multicolumn{5}{|l|}{ Moderate disease } \\
\hline $\begin{array}{l}\text { Pneumonia } \\
\text { Dyspnoea } \\
\text { Moderate } \\
\text { hypoxemia }\end{array}$ & $\begin{array}{c}\text { Headaches } \\
\text { Dizzines, Myalgia } \\
\text { Ataxia, } \\
\text { Encephalopathy } \\
\text { Depression }\end{array}$ & $\begin{array}{l}\text { Loss of apetite } \\
\text { Abdominal pain } \\
\text { Bloating }\end{array}$ & $\begin{array}{c}\text { Cardiac inflammation } \\
\text { Thromboembolism } \\
\text { Cytokine storm }\end{array}$ & Acute renal injury \\
\hline \multicolumn{5}{|l|}{ Severe disease } \\
\hline $\begin{array}{l}\text { Severe hypoxemia } \\
\text { Acute respiratory } \\
\text { distress syndrome } \\
\text { Respiratory failure } \\
\text { and death }\end{array}$ & $\begin{array}{c}\text { Cerebrovascular } \\
\text { disease } \\
\text { Meningoencephalitis } \\
\text { Seizures } \\
\text { Gullain-Barré } \\
\text { syndrome } \\
\text { Coma }\end{array}$ & $\begin{array}{c}\text { Gastrointestinal } \\
\text { bleeding } \\
\text { Gastrointestinal viral } \\
\text { dissemination }\end{array}$ & $\begin{array}{c}\text { Cardiomyopathy } \\
\text { Acute heart failure } \\
\text { Pulmonary embolism } \\
\text { Disseminated } \\
\text { intravascular } \\
\text { coagulation }\end{array}$ & Renal failure \\
\hline
\end{tabular}

MIS-C can develop 4 to 6 weeks after primary COVID-19 infection, which is usually mild or asymptomatic. The main symptoms are persistent fever (more than 3 to 5 days), gastrointestinal symptoms (abdominal pain, vomiting, diarrhea), evidence of mucocutaneous inflammation (rash, conjunctivitis, oromucosal changes), lymphopenia, and high levels of circulating acute phase reactants (CRP, IL-6, ferritin and procoagulant factors). Severe MIS-C includes hypotension or shock and evidence of cardiac involvement with myocarditis, myocardial dysfunction and coronary artery changes. Fatal cases are rare $(2 \%)$ (Vogel et al. 2021). The syndrome has clinical similarities with Kawasaki disease (KD) but also some distinct features. MIS-C affects older children and adolescents, which is in marked contrast to the epidemiology of $\mathrm{KD}$, which occurs predominantly in children 5 years of age or less and with a peak incidence at 9 to 11 months of age. MIS-C manifests with a higher incidence of myocardial dysfunction and gastrointestinal symptoms than KD. Thrombocytopenia is typical of MIS-C and usually not observed in KD. Kawasaki disease shock syndrome (KDSS), a rare form of KD, has many similarities to MIS-C and is often associated with myocarditis and prolonged myocardial dysfunction (Yasuhara et al. 2021).

A subset of adult patients experiences a severe hyperinflammatory response known as MIS-A during primary SARS-CoV-2 infection. MIS-A is a severe illness in a person aged over 21 years, with laboratory evidence of current or previous (within 12 weeks) SARSCoV-2 infection, severe extrapulmonary organ dysfunction (including thrombosis), laboratory evidence of severe inflammation, and the absence of severe respiratory disease. The severity of cardiac dysfunction, incidence of thrombosis and mortality of MIS-A may be 
higher than MIS-C (Vogel et al. 2021).

Other hyperinflammatory syndromes are primary and secondary haemophagocytic lymphohistiocytosis (HLH) characterized by fever, elevated liver enzymes, hyperferritinaemia, hypertrygliceridaemia, hypofibrinogenaemia, thrombocytepenia and splenomegaly. SARS-CoV-2, like other respiratory viruses, may be considered a potential etiological trigger of HLH. Mehta et al. (2020) have suggested a close association and recommended that all patients with severe COVID-19 should be screened for HLH. Loscocco (2020) argue that most of these patients develop ARDS, which shares some HLH features, rather than present systemic macrophage activation (macrophage activation syndrome, MAS), which is the hallmark of HLH. The frequency of HLH in adult patients with severe systemic COVID-19 was described as less than $5 \%$. In children with MIS-C, the estimated frequency of MAS is higher than in adults (Retamozo et al. 2021, Mehta et al. 2020, Loscocco 2020).

\section{Physiological background of COVID-19 infection}

To explore the differences between children and adults with COVID-19 infection, we should start with the physiological background of COVID-19 infection. The main differences between children and adults are in the expression of viral receptors, which are required for viral entry, innate immune response and cytokine production, and mechanisms of adaptive immune response. Children and adults have many factors which contribute to a different course of COVID-19. These factors include comorbidities, trained immunity by viral exposure to other respiratory viruses, serum levels of vitamin $\mathrm{D}$, etc. This section of the article examines the pathophysiology of COVID-19 and its differences between children and adults.

\section{SARS-CoV-2 characteristics}

The novel coronavirus named SARS-CoV-2 belongs to the Coronaviridae family of viruses. Coronaviruses are large enveloped viruses ( 80 to $120 \mathrm{~nm}$ ) which contain single-stranded ribonucleic acid (RNA). Their genome is one of the largest RNA viruses, containing 27,000 to 32,000 nucleotides. They are divided into four genera according to specific genomes: alpha, beta, gamma, and delta. The alpha and beta coronaviruses infect only mammals. The most dangerous of the coronaviruses, SARS-CoV (Severe Acute Respiratory Syndrome Coronavirus), MERS-CoV (Middle East Respiratory Syndrome Coronavirus) and SARS-CoV-2 (Severe Acute Respiratory Syndrome Coronavirus 2) are betacoronaviruses (Rabi et al. 2020). The genome of SARS-CoV-2 has an $82 \%$ nucleotide identity with SARS-CoV and contains 14 open reading frames (ORFs) (Chan et al. 2020). It encodes 16 nonstructural proteins (Nsp1-16), 4 structural proteins and 9 accessory proteins (ORF 3a, 3b, 6, 7a, 7b, 8, 9b, 9c, and 10) (Chan et al. 2020). The structural proteins are spike $(\mathrm{S})$, membrane $(\mathrm{M})$, nucleocapsid $(\mathrm{N})$ and viral envelope (E). The most important of them is the spike protein, which is a binding protein that interacts with cell surfaces. Mutations in the spike protein structure determine the diversity of SARS-CoV-2 coronavirus variants, affect their antigenicity and the binding of neutralizing antibodies (Harwey et al. 2021). To understand the differences between the immune response in children and adults and the possible modifying factors, it is necessary to mention the life cycle of SARS-CoV-2.

\section{SARS-CoV-2 receptors}

The most common manner of virus transmission is droplet infection. SARS-CoV-2 interacts with the airway epithelium through the $\mathrm{S}$ protein. Investigations of the SARS-CoV infection have found that the virus interacts with angiotensin converting enzyme 2 (ACE2) receptors, an observation confirmed by other SARSCoV-2 studies (Chen et al. 2020, Walls et al. 2020). ACE2 receptors are expressed predominantly in the upper airway epithelium, lungs (type II pneumocytes), kidney and bladder, myocardium, ileum, and colon (Salamanna et al. 2020). SARS-CoV-2 bound to ACE2 receptors in the lungs forms a complex. This complex is subsequently proteolytically cleaved by type 2 transmembrane protease (TMPRSS2), leading to $\mathrm{S}$ protein activation and facilitating SARS-CoV-2 entry into cells (Hoffmann et al. 2020). The level of ACE2 expression in these organs is relatively low, and according to current knowledge, other receptors are involved in the pathogenesis of SARS-CoV-2 penetration into cells (Fig. 2).

The first is CD147 (basigin/EMMPRIN/ extracellular matrix metalloproteinase inducer) and the second is GRP78/ BiP (Glucose Regulating Protein 78/Binding immunoglobulin protein). $\mathrm{CD} 147$ is a transmembrane glycoprotein, a member of the immunoglobulin superfamily. CD147 is a pleiotropic 
molecule critical during fetal development and retinal function and has been shown to play a role in thymic $\mathrm{T}$ cell development and many neurological processes (Muramatsu et al. 2003, Zhou et al. 2005). Wang et al. (2020) reported a direct interaction between CD147 and the SARS-CoV-2 spike protein. The loss or blockage of CD147 inhibits SARS-CoV-2 replication; by contrast, CD147 overexpression encourages virus infection. SARS-CoV-2 virions enter host cells through the CD147spike protein route by endocytosis. The presence of
CD147 on peripheral lymphocytes can explain the lymphopenia observed in patients with severe COVID-19 infection (Wang et al. 2020). GRP78 is a chaperone usually located in the endoplasmic reticulum of cells. Upon cell stress, overexpression of GRP78 initiates and the proteins translocate to cell membranes, where they can mediate virus entry (Ibrahim et al. 2019). This has been observed in studies of SARS-CoV-2 (Ibrahim et al. 2020).

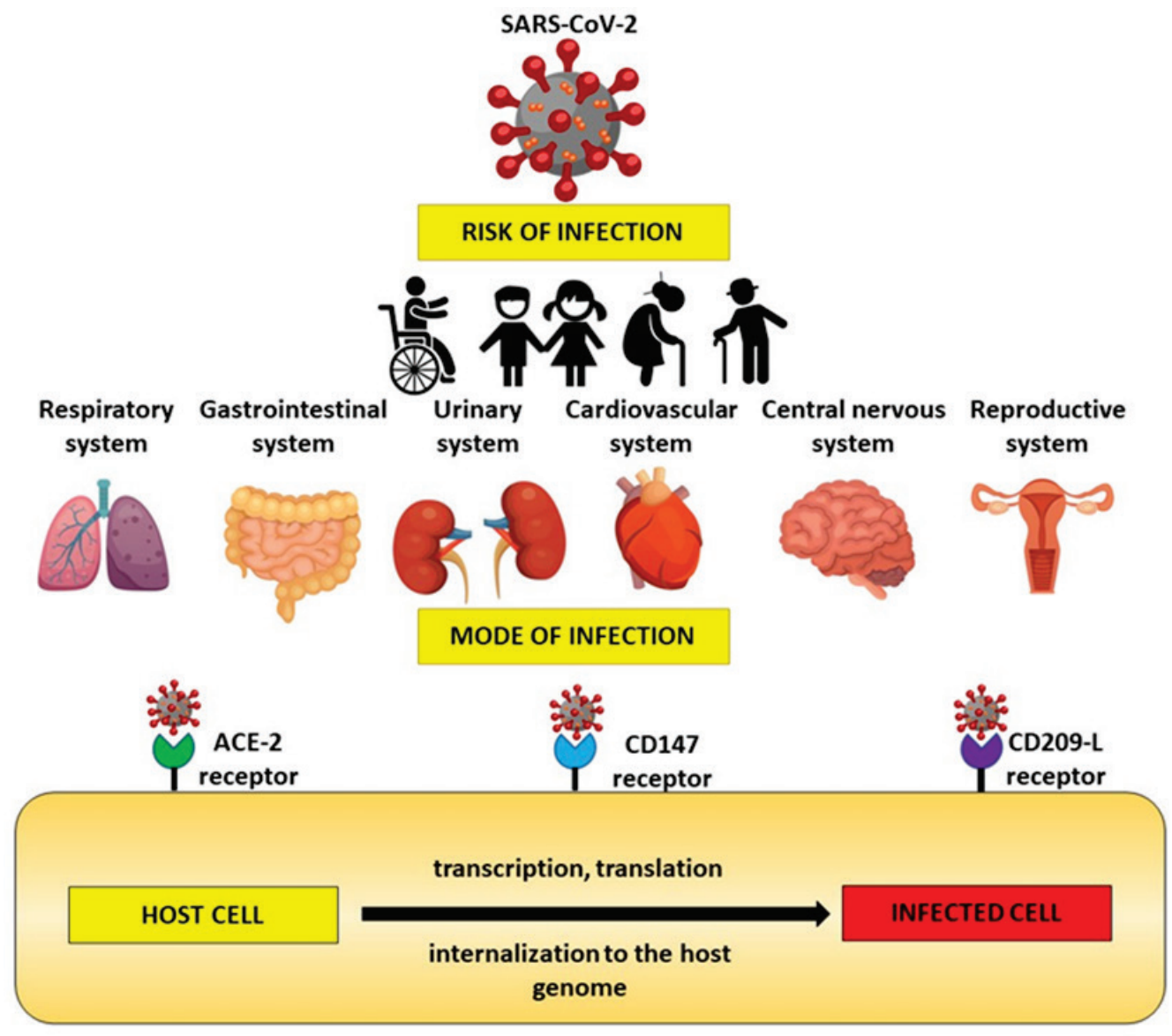

Fig. 2. Coronavirus infectivity and target receptors of interaction.

\section{Innate immune response to SARS-CoV-2}

The first defense against any pathogen is the innate immune response. After viral penetration of the airways, pathogen associated molecular patterns (PAMPs) are recognized by antigen presenting cells, mainly tissue macrophages and dendritic cells. PAMPs interact with the pathogen recognition receptors (PRRs) of cells during the innate immune response and produce inflammatory cytokines (TNF, IL-1b, IL-6, IL-8, and IL-12) and interferons (Kumar et al. 2009). Neutrophils and natural killer (NK) cells are involved in the amplification of inflammation. They migrate to the site of local inflammation and have the ability to phagocytose or act as "natural" killers. An important step in the subsequent initiation of an adaptive immune response and control of viral replication is the production of type I interferon. The antiviral state is induced in the cell through the stimulation of the synthesis of two enzymes: protein kinase and oligoadenylate synthetase. Protein kinase phosphorylates and inactivates translation factors to stop translation in the cell. The second enzyme, oligoadenylate synthetase, catalyses the formation of 
special oligonucleotides which activate RNase L, degrading mRNA and rRNA (Kindler 2016). In interferon pathways, the signals from PRRs are transduced to the nucleus through the activation of a stimulator of IFN genes (STING) and a mitochondrial antiviral-signalling protein (MAVS). This leads to phosphorylation of interferon regulatory factors (IRFs), mainly IRF 3 and 7. Phosphorylated dimers of IRF3/7 translocate to the nucleus, where they can trigger expression of IFN and interferon-stimulated genes (ISGs). Interferon-stimulated genes and other IFN-Iinduced molecules (including proinflammatory cytokines) have diverse functions (Schneider et al. 2014). The result of their action is to stop translation, increase the breakdown of nucleic acids of the virus, induce tissue repair, and trigger a prolonged adaptive immune response against viruses.

The type I IFN response is a crucial factor in the severity of disease, as observed in MERS infection (Shokri et al. 2019). SARS-CoV-2 has different tools to affect IFN-I induction and IFN-I signalling pathways. Viral ORFs and non-structural proteins can impair viral sensing, activation of IRF3, downstream signalling, and the expression of IFN-I. After the production of IFN-I, they can inhibit binding of IFN-I to its receptors on cell surfaces and disable JAK/STAT1 activation, which is needed for IFN-I actions (Kopecky-Bromberg et al. 2007, Lu et al. 2011, Ribero et al. 2020). The total result is impaired viral response, persistence of viral particles in cells, and induction of a cytokine storm. High serum levels of proinflammatory cytokines (IL-2, IL-6, IL-7, IL-10, G-CSF, IP-10, MCP-1, MIP-1 $\alpha$ and TNF- $\alpha$ ), neutrophilia and lymphopenia have been observed in patients with severe COVID-19 infection (Xu et al. 2020, Prompetchara et al. 2020, Bobcakova et al. 2021).

In patients with severe COVID-19 infection, the role of NLR family pyrin domain containing 3 (NLPR3) inflammasome should also be estimated. Inflammasomes are macromolecular complexes in macrophages. They react to different stimuli, and the result of their activation is the production of active IL-1 $\beta$. Patients with a sustained and unregulated NLRP3-dependent inflammatory response can develop severe inflammation and severe clinical symptoms through pyroptosis induced by an NLRP3 inflammasome. SARS-CoV ORF8b is reported to activate NLRP3 by binding to the leucine rich-repeat (LRR) domain, suggesting a mechanism of coronavirus-induced NLRP3 direct activation (Shi 2019). Gene variants in genes which encode inflammasome proteins may also contribute to different disease outcomes and may be the cause of the variable response to SARS-CoV-2 (Freeman and Swartz 2020, Merad and Martin 2020).

\section{Adaptive immune response to $\mathrm{SARS}-\mathrm{CoV}$-2}

Antigen presenting cells (APCs), mainly dendritic cells, represent a key link in the adaptive immune response in viral infections. MHC class II molecules on APCs present viral peptides through the $\mathrm{T}$-cell receptors (TCR) on naive $\mathrm{T}$ cells, with subsequent maturation and differentiation. $\mathrm{T}$ cells differentiate into $\mathrm{T}$ helper cells $\left(\mathrm{CD} 4^{+}\right)$and cytotoxic $\mathrm{T}$ cells $\left(\mathrm{CD} 8^{+}\right)$. $\mathrm{CD} 4{ }^{+} \mathrm{T}$ cells are crucial in the production of cytokines, which recruit phagocytes and activate other leukocytes. They also interact with $\mathrm{B}$ cells. $\mathrm{CD}^{+} \mathrm{T}$ cells can find and kill virally infected epithelial cells through the release of cytotoxic factors. They are stored inside granules in cytoplasm. One of these mediators is perforin, a protein which can produce pores in cell membranes. Another is granzyme, which enters target cells through these holes produced by perforin. They can initiate apoptosis of infected cells. Another important component of antiviral response is $\mathrm{B}$ cell activation and antibody production. Antibodies can either neutralize the virus by binding to viral surface proteins or agglutinate viral particles together, thereby being more easily recognized by immune cells, or induce phagocytosis and activate the complement system (Felsenstein et al. 2020).

One important indication of SARS-CoV-2 infection in severe cases is lymphopenia and neutrophilia in peripheral blood. Lymphopenia (according to studies, total lymphocyte count $<1 \times 10^{9} / 1$ ) is associated with a severe course of the disease and poorer outcome (Huang et al. 2020). The explanations for lymphopenia in COVID-19 infection differ between authors. The main reasons are presumably the increased destruction of lymphocytes induced by the virus or cytokines, or either the increased apoptosis of lymphocytes or redistribution of lymphocytes from peripheral blood to the infected lungs (Tan et al. 2020, Terpos et al. 2020, Song et al. 2020). In the present article, we have already mentioned that peripheral lymphocytes express CD147, which is one of the receptors for virus entry, and can thus increase direct entry of viral particles and the destruction of virally infected lymphocytes (Wang et al. 2020). A notable decrease in the total count of peripheral $\mathrm{CD}^{+} \mathrm{T}$ cells and both subsets of $\mathrm{CD}^{+} \mathrm{T}$ and $\mathrm{CD}^{+} \mathrm{T}$ cells has been observed in patients with severe COVID-19 infection 
(Chen et al. 2020, Diao et al. 2020, Song et al. 2020, Wang et al. 2020, Jiang et al. 2020). The total counts of $B$ cells and NK cells in peripheral blood do not indicate any association with disease severity (Bobcakova et al. 2021, Jesenak et al. 2020). Another interesting fact is that $\mathrm{T}$ cells show a decrease depending on the age of the patient (the most severe decrease was seen in patients over 60 years) (Diao et al. 2020). This phenomenon in connection with physiological lymphocytosis, which is observed in differential leukograms in children between the fifth day and fifth year of age, might also explain the far better course of COVID-19 infection in children. Not only a decrease in total $\mathrm{T}$ cell count but also $\mathrm{T}$ cell exhaustion can contribute to a worse outcome in the disease. In our previous study (of 21 COVID-19 patients), in-hospital death was associated with a significantly higher proportion of both PD- $1^{+} \mathrm{CD}^{+} \mathrm{CD}^{+}$and PD- $1^{+} \mathrm{CD} 3^{+} \mathrm{CD} 8^{+}$cells than in a group of survivors (Bobcakova et al. 2021). Similar results have also been observed in other studies (Wang et al. 2020, Song et al. 2020).

\section{Differences between children and adults with SARS-CoV-2 infection}

Up to now, we can conclude that children generally have a better outcome from COVID-19 infection. Many different theories have been proposed as a possible explanation. In the present review, we examine the most interesting and plausible of them. The main proposed theories are (Table 2):

1) Differences in receptors and affinity to SARS-CoV-2 in children and adults;

2) Differences in type I interferon (IFN) production;

3) Differences in innate, trained immunity in children;

4) Differences in adaptive immunity and antibody production;

5) Associated comorbidities in adults;

Possibly protective effects of live attenuated vaccines and higher levels of vitamin $\mathrm{D}$ in children.

Differences in receptors and their affinity to SARS-CoV-2 in children and adults

As previously mentioned, the most important receptor for SARS-CoV-2 in the respiratory tract is ACE2. However, another two receptors for SARS-CoV-2 have been identified: CD147 and GRP78. Another factor required for entry of the virus into cells is TMPRSS2, a proteinase (required for cleavage of the $\mathrm{S}$ protein of the virus) associated with ACE2. Differences in the abovementioned receptors and proteinase have been identified in children and adults. Expression of ACE2 in the nasal epithelium is different in children compared to adults. Bunyavanich et al. (2020) found age dependent ACE2 gene expression in the nasal epithelium. ACE2 gene expression was lowest in children $(<10$ years $)$ and increased with age. The study was limited by not containing adults older than 60 years (Bunyavanich et al. 2020). The suggested mechanism is that fewer viral particles can attach to the respiratory epithelium, which is why children are affected with COVID-19 less frequently and with less severity than adults. Expression of ACE2 gene increases with age and can be modulated by environmental factors, for example, tobacco smoking increases ACE2 gene expression in bronchial epithelial cell samples (Aguiar et al. 2020, Leung et al. 2020). Another interesting fact is the different affinity of ACE2 to SARS-CoV-2 in adults and children. Children have a lower affinity of ACE2 receptors to SARS-CoV-2 (Muus et al. 2020). Expression of TPMRSS2 and CD147 also appears to increase with age, but more studies are needed to confirm this observation (Leung et al. 2020, Schuler et al. 2020, Aquiar et al. 2020).

\section{Differences in type I interferon production}

Type I interferon responses are required for early destruction of the virus and activation of host defense mechanisms. SARS-CoV-2 has a long incubation period and the ability to delay and decrease the production of interferon type I. Yoshikawa et al. (2010) studied the dynamics of innate immune responses to SARS-Co-V infection and observed that activation of the interferon regulatory factors (namely IRF 3/7) occurred not sooner than $48 \mathrm{~h}$ post-inoculation (Yoshikawa et al. 2010). Children have an advantage over adults. In the first years of life, they suffer from recurrent respiratory infections and thus have stronger and trained innate immune responses against viruses. It appears that children are capable of a quicker IFN response during the incubation period of a virus and have a lower threshold for an IFN antiviral response (Simon et al. 2015).This suggests that their immune systems can act more rigorously and quickly against SARS-CoV-2. Upregulation of type I and type III IFN-associated gene expression in the tracheobronchial epithelium has also been observed in children before infection (Simon et al. 2015). Higher levels of IL-17A and IFN- $\gamma$ have also been found in children with COVID-19 (Pierce et al. 2020). Another 
cause of difference and severity is pre-existing autoantibodies against type I interferons in adults. Bastard et al. (2020) found that the age-related increase in autoantibodies against type I interferon was associated with severe COVID-19 pneumonia (Bastard et al. 2020).

Table 2. Differences in pathomechanisms between children and adults with COVID-19.

\section{Differences in pathomechanisms between children and adults with COVID-19}

Lower expression of $A C E 2$ gene in nasal epithelium in children (Bunyavanich et al. 2020)

Receptors and their affinity to Lower affinity of ACE-2 receptors to SARS-CoV-2 in children (Muus et al. SARS-CoV-2 2020)

Increasing expression of viral receptors TPMRSS2 and CD 147 with age (Leung et al. 2020, Schuler et al. 2020, Aquiar et al. 2020)

Lower threshold for IFN antiviral response in children (Simon et al. 2015)

Upregulation of type I and type III IFN-associated gene expression in tracheobronchial epithelium in children before infection (Simon et al. 2015)

Type I interferon production

Higher levels of IL-17A and IFN- $\gamma$ in children with COVID-19 (Pierce et al. 2020)

Pre-existing auto-antibodies against type I interferons associated with severe COVID-19 pneumonia in adults (Bastard et al. 2020)

\begin{tabular}{lr}
\hline "Trained” innate immunity & $\begin{array}{c}\text { Higher exposure to respiratory viruses in children: the mechanism of cross- } \\
\text { reactivity and „,memory“ of innate immune cells (Netea } \text { et al. } 2020)\end{array}$ \\
\hline Associated comorbidities & Higher prevalence of risk comorbidities in adults \\
\hline Inflammaging in adults & $\begin{array}{c}\text { Higher capability of mounting the pro-inflammatory cytokine storm in adults } \\
\text { Increased activity of NLRP3 inflammasome associated with severe COVID-19 in } \\
\text { adults (Freeman and Swartz 2020) }\end{array}$ \\
\hline
\end{tabular}

The protective effect of live vaccines due to induction of „trained“ immunity,

Protective effects of live vaccines heterologous lymphocyte activation and enhanced cytokine production observed

after BCG, MMR and polio vaccines (Giamarellos-Bourboulis et al. 2020, Moorlag et al. 2019)

Hypovitaminosis D is less frequent in infants and young children due to recommended supplementation in the first year of life

Vitamin D levels

Lower levels of vitamin D were correlated with increased severity of COVID-19 in adults (Panagiotou et al. 2020, Maghbooli et al. 2020)

Developing $\mathrm{T}$ cell response in the first year of life: children less than 1 year have

T cell response more severe disease course (Gallo et al. 2021).

Immunosenescence in older adults: the age more than 75 years is connected with higher severity and mortality (O'Driscoll et al. 2021)

Differences in innate immunity and trained immunity in children and adults

The most important cellular particles of innate immunity are neutrophils and macrophages. Both are capable of phagocytosis, production of proinflammatory cytokines, and amplification of the immune response.
They form an important connection between innate and adaptive immunity. However, overreaction of these particles is also dangerous, which we can observe in severe multisystem inflammatory syndromes associated with COVID-19 in children and young adults.

From the neonatal period into adulthood, the 
immune response develops progressively. In the first few years, the most important mechanisms are the processes of innate immunity. The role of interferon type I is also significant. The term "trained immunity" refers to the epigenetic changes and metabolic reprogramming in innate immune cells after exposure to certain stimuli (infections, vaccinations, etc.), leading to certain types of "memory" (Netea et al. 2020). Children are in frequent contact with many respiratory infections (also less pathogenic coronaviruses), which can lead to a trained immune response to these diseases. The mechanism of cross-reactivity to these viruses and SARS-CoV-2 may be why the immune systems of children can kill the virus more effectively (Netea et al. 2020). In children with COVID-19, neutrophilia and neutropenia can be seen in only $6 \%$ and $4.6 \%$, respectively, of cases (Henry et al. 2019). The other approximately $90 \%$ of children infected with SARS-CoV-2 have normal neutrophil counts. In adults with COVID-19, neutrophilia on admission is associated with poor disease outcome (Wang et al. 2020). Neutrophils in patients with COVID-19 are capable of forming neutrophil extracellular traps (NETs). They are known as "traps" because they trap circulating platelets, red blood cells and neutrophils. The result of this process is vascular instability and hypercoagulability associated with endothelial damage and cytokine release and systemic inflammation. The differences between children and adults in the formation of NETs are not known (Zhuo et al. 2020). Another specific problem in adults and seniors is inflammaging, which refers to a chronic proinflammatory state of the organism which occurs with aging. In connection with comorbidities such as diabetes or cardiovascular diseases, adult patients may experience the development of severe hyperinflammation and a cytokine storm (Franceschi et al. 2018). Logically, children are less susceptible to the development of a proinflammatory cytokine storm because their innate immune response in the first few years of life is not so strongly competent. Interestingly, children with COVID-19 admitted to hospital have higher serum levels of IL-17A and IFN- $\gamma$, but not TNF- $\alpha$ or IL-6 (Pierce et al. 2020). A similar pathomechanism associated with ageing has also been observed in macrophages: severe COVID-19 is marked by the hyperactivation of macrophages. Studies of SARS-CoV and MERS-CoV have shown that acute infection induced by macrophage and neutrophil invasion results in high levels of proinflammatory cytokine, leading to acute lung injury, acute respiratory distress syndrome, and death
(Channappanavar et al. 2017). In the most severe COVID-19 cases, a marked increase in IL-6 and ferritin levels was observed (Ruan et al. 2020). Macrophage hyperactivation in older adults perhaps accounts for increased morbidity and mortality seen in this type of acute infection.

The main macromolecular component required to activate an immune response is an inflammasome. Inflammasome mutations are associated with certain autoinflammatory diseases (Gattorno et al. 2008). Uncontrolled or partially controlled activation of inflammasome leads to the production of excess amounts of proinflammatory cytokines, mainly IL-1 $\beta$ (Yang et al. 2012). Increased activity of the NLRP3 inflammasome is associated with severe COVID-19 in older patients (Freeman and Swartz 2020). Variations in genes which encode inflammasome proteins may also contribute to different disease outcomes and may be the cause of the variable response to SARS-CoV-2 (Freeman and Swartz 2020, Merad and Martin 2020).

Differences in adaptive immunity and antibody production

The most important cells for adaptive immune response are $\mathrm{T}$ cells. Decrease in $\mathrm{CD} 4^{+}$and $\mathrm{CD} 8^{+} \mathrm{T}$ cells and exhaustion of $\mathrm{T}$ cells are linked to severe courses of COVID-19 infection and poorer outcomes. T cell differentiation and selection (either positive or negative) occurs in the thymus. Immunosenescence observed in the elderly is a possible reason for ineffective clearance of SARS-CoV-2. Immunosenescence is the term used for the decline in innate immunity (mainly in reduced neutrophil and macrophage activation and cytotoxic activity of NK cells) and dysregulated $\mathrm{T}$ cell response (increase in anergic memory $\mathrm{T}$ cells, decline in naive $\mathrm{T}$ cells, exhaustion of $\mathrm{T}$ helper cells, $\mathrm{T}$ cytotoxic cells and $\mathrm{B}$ cells) due to thymic involution. An age of 75 years or more is associated with greater disease severity and higher mortality (O'Driscoll et al. 2021).

A very similar situation can be observed in children less than 1 year old. The immune system develops very quickly after birth, but in the first year, cellular immunity in children is not very competent. Neonatal $\mathrm{T}$ and $\mathrm{B}$ cells overexpress the surface features of naive cells (CD45RA). T cells are immature and do not provide sufficient assistance to $\mathrm{B}$ cells. $\mathrm{CD}^{+}$cells with $\mathrm{a}_{\mathrm{h}} 2$ type immune response and relatively higher production of IL-4, IL-5, IL-13 predominate. After birth, the highest proportion of $\mathrm{T}$ cells is represented by 
T regulatory cells $\left(\mathrm{T}_{\text {reg }}\right)$, which gradually decrease in number. Neonates also have a reduced $B$ cell mediated humoral response, which is delayed and shorter, and the produced antibodies have lower affinity. During the neonatal period, B1 lymphocytes predominate, producing IL-10 and TGF- $\beta$ and stimulating a $\mathrm{T}_{\mathrm{h}} 2$ response. Suppression of the $T_{h} 1$ response may reduce the risk of an exaggerated proinflammatory response upon massive exposure to post-birth antigenic stimuli to protect its own structures (Ygberg and Nilsson 2012, Simon et al. 2015, Jeseňák et al. 2012). Immaturity of the immune system is the reason for increased susceptibility to infections during the perinatal period. The greater the degree of immaturity due to premature birth, the higher the risk of serious infection and sepsis. The components of non-specific immunity in infancy mature first, while the functions of neutrophils, macrophages and dendritic cells remain low. Around the first year, the $\mathrm{T}_{\mathrm{h}} 1$ response and production of memory $\mathrm{T}$ cells increases (Ygberg and Nilsson 2012, Simon et al. 2015). A very young age (less than 1 year) is associated with a severer course of disease (Gallo et al. 2021).

It appears that the most significant components in the immune response to SARS-CoV-2 are T cells and an innate immune system. Antibodies against SARSCoV-2 are also important components in the immune response, the most significant being $\operatorname{IgG}$ antibodies, which target the S protein of the virus. A study by Weisberger et al. (2021) found the presence of anti-spike (S) IgG, IgM and IgA antibodies and anti-nucleocapsid (N) IgG antibodies in adult COVID-19 cohorts. Children with or without MIS-C showed a lower breadth of anti-SARS-CoV-2-specific antibodies, predominantly $\mathrm{IgG}$ antibodies generated to target the $\mathrm{S}$ protein but not the N protein. Children with or without MIS-C had a lower neutralizing activity than both adult COVID-19 cohorts, indicating a reduced protective serological response (Weisberger et al. 2021). Another factor in the production of antibodies against SARS-CoV-2 is that children often have limited upper respiratory tract infections associated with shorter durations of antibody production (Galanti and Shaman 2020). Children are therefore probably more susceptible to reinfection with SARS-CoV-2.

\section{Associated comorbidities in adults}

Pre-existing comorbidities, such as cardiovascular disease, chronic kidney disease, chronic obstructive pulmonary disease, diabetes mellitus, hypertension, immunosuppression, obesity, and sickle cell disease all predispose patients to an adverse clinical course and increased risk of intubation and death. Cancers, particularly hematological and pulmonary malignancies, are also thought to be major comorbidities associated with poor COVID-19 outcomes (Gallo et al. 2021). All can lead to pre-existing cellular stress with hyperinflammatory states and the over-production of proinflammatory cytokines. Logically, this can lead to greater predisposition to a cytokine storm, hypercoagulability, ARDS, and multiorgan dysfunction syndrome. These comorbidities, of course, have a higher prevalence in adults than children. In children, other comorbidities have been identified and include primary immunodeficiencies, syndromological diseases, autism, neurological diseases, and autoimmune diseases. These conditions and very young age (less than 1 year) are associated with a severer course of disease (Gallo et al. 2021).

Immunological effects of live vaccines and higher levels of vitamin $D$ in children

To complete the present review, another two factors which may contribute to a less severe course of COVID-19 in children should be mentioned. These two factors play an important role in every viral infection and are not specific to COVID-19. Children are vaccinated according to the national immunization programme in each country: in most of these countries, they receive two doses of the MMR (measles, mumps and rubella) vaccine up to the age of five, and in some, also mandatory vaccination against tuberculosis (BCG). Both of these vaccines are live attenuated vaccines. Previous reviews have shown that vaccination against tuberculosis protects against viral pathogens (experimental studies have shown that the BCG vaccine protects against various DNA and RNA viruses, including herpes and influenza viruses). These effects are thought to be mediated through the induction of trained immunity and heterologous lymphocyte activation, resulting in enhanced cytokine production, macrophage activity, T-cell responses and antibody titres (Giamarellos-Bourboulis et al. 2020, Moorlag et al. 2019). With the same mechanism, the MMR and oral polio vaccines can also contribute to differences in the severity of COVID-19 (Franklin et al. 2020, Chumakov et al. 2020).

Vitamin D deficiency appears to negatively correlate with disease severity and radiological findings. Toddlers and infants are supplied daily with vitamin D to 
prevent rickets; vitamin $\mathrm{D}$ deficiency is therefore less frequent in this group. WHO recommendations for daily vitamin $\mathrm{D}$ intake in infants less than 1 year of age, based on randomized controlled trials, are 5 to $10 \mu \mathrm{g}$ daily (Bouillon 2017). Vitamin D has multiple effects on the innate and adaptive immune response. Vitamin $\mathrm{D}$ affects the proliferation of $T$ cells, regulates the $T_{h} 1 / T_{h} 2$ cellular response, induces the formation of $\mathrm{T}_{\text {reg }}$ lymphocytes, and stimulates immune tolerance. It also affects the production of proinflammatory cytokines, mainly by reducing the production of $\mathrm{T}_{\mathrm{h}} 1$ type proinflammatory cytokines and promoting the production of $\mathrm{T}_{\mathrm{h}} 2$ type cytokines (Arnsonet et al. 2007, Holick 2007). Vitamin D levels are lower in older age groups, especially males (Mosekilde 2007). De Smet et al. (2020) found lower vitamin D levels in patients with COVID-19 than controls matched according to sex, age and season (De Smet et al. 2020). Vitamin D levels negatively correlate with the severity of radiological findings. Two other studies have found a correlation between low vitamin D levels and COVID-19 severity and mortality (Panagiotou et al. 2020, Maghbooli et al. 2020). The risk factors in vitamin D deficiency are very similar to the factors associated with a severe course of COVID-19, highlighting the importance of the vitamin D.

\section{Conclusions}

COVID-19 infection is still largely a mystery.
More knowledge has offered many answers and different therapeutic strategies for specific groups of patients, but many questions remain unanswered and unresolved. All the proposed differences in the pathomechanism of the immune response to SARS-CoV-2 need to be verified in larger patient cohorts. We can conclude that despite all the various differences in the immune response to SARSCoV-2, the most important component is the innate immune response. The differences in response and the capabilities of the organism to develop a proinflammatory state and the cytokine storm are directly related to the severity of the disease. Perhaps COVID-19 is another important lesson in learning about trained innate immunity and interferon pathways and a challenge to immunologists and researchers to define new and effective therapeutic and prevention strategies.

\section{Conflict of Interest}

There is no conflict of interest.

\section{Acknowledgements}

This publication has been produced with the support of the project KEGA 048UK-4/2021 and Integrated Infrastructure Operational Program for the project: Creation of a Digital Biobank to support the systemic public research infrastructure, ITMS: 313011AFG4, co-financed by the European Regional Development Fund.

\section{References}

AGUAIR JA, TREMBLAY BJ, MANSFIELD MJ, WOODY O, LOBB B, BANERJEE A, CHANDIRAMONAH A, TIESSEN N, CAO Q, DVORKIN-GHEVA A, REVILL S, MILLER MS, CARLSTEN C, ORGAN L, JOSEPH C, JOHN A, HANSON P, AUSTIN RC, MCMANUS BM, JENKINS G, ET AL.: Gene expression and in situ protein profiling of candidate SARS-CoV-2 receptors in human airway epithelial cells and lung tissue. Eur Respir J 56: 2001123, 2020. https://doi.org/10.1183/13993003.01123-2020

ARNSON Y, AMITAL H, SHOENFELD Y: Vitamin D and autoimmunity: new aetiological and therapeutic considerations. Ann Rheum Dis 66: 1137-1142, 2007. https://doi.org/10.1136/ard.2007.069831

BASTARD P, ROSEN LB, ZHANG Q, HOFFMANN HH, CHBIHI M, LE VOYER T, ROSAIN J, PHILIPPOT Q, SEELEUTHER Y, GERVAIS A, MATERNA M, DE OLIVIERA PMN, MAIA MLS, DINIS ANO BOM AP, AZAMOR T, ARAUJO DA CONCEICAO D, GOUDORIS E, HOMMA A, SLESAK G, SCHAFER J, ET AL.: Auto-antibodies against type I IFNs in patients with life-threatening COVID-19. J Exp Med 218: e20202486. https://doi.org/10.1084/jem.20202486

BOBAN M: Novel coronavirus disease (COVID-19) update on epidemiology, pathogenicity, clinical course and treatments. Int J ClinPract 75: e13868, 2021. https://doi.org/10.1111/ijcp.13868

BOBCAKOVA A, PETRISKOVA J, VYSEHRADSKY R, KOCAN I, KAPUSTOVA L, BARNOVA M, DIAMANT Z, JESENAK M: Immune profile in patients with COVID-19: Lymphocytes exhaustion markers in relationship to clinical outcome. Front Cell Infect Microbiol 11: 646688, 2021. https://doi.org/10.3389/fcimb.2021.646688 
BOUILLON R: Comparative analysis of nutritional guidelines for vitamin D. Nat Rev Endocrinol 13: 466-479, 2017. https://doi.org/10.1038/nrendo.2017.31

BUNYAVANICH S, DO A, VICENCIO A: Nasal gene expression of angiotensin-converting enzyme 2 in children and adults. JAMA 323: 2427-2429, 2020. https://doi.org/10.1001/jama.2020.8707

CASTAGNOLI R, VOTTO M, LICARI A, BRAMBILLA I, BRUNO R, PERLINI S, ROVIDA F, BALDANTI F, MARSEGLIA GL: Severe Acute Respiratory Syndrome coronavirus 2 (SARS-CoV-2) infection in children and adolescents: a systematic review. JAMA Pediatr 174: 882-889, 2020. https://doi.org/10.1001/jamapediatrics.2020.1467

CHAN JF, KOK KH, ZHU Z, CHU H, TO KK, YUAN S, YUEN K: Genomic characterization of the 2019 novel human-pathogenic coronavirus isolated from a patient with atypical pneumonia after visiting Wuhan. Emerg Microbes Infect 9: 221-236, 2020. https://doi.org/10.1080/22221751.2020.1719902

CHANNAPPAVANAR R, PERLAM S: Pathogenic human coronavirus infections: causes and consequences of cytokine storm and immunopathology. Semin Immunopathol 39: 529-539, 2017. https://doi.org/10.1007/s00281-017-0629-x

CHEN R, SANG L, JIANG M, YANG Z, JIA N, FU W, XIE J, GUAN W, LIANG W, NI Z, HU Y, LIU L, SHAN H, LEI C, PENG Y, WEI L, LIU Y, HU Y, PENG P, WANG J, LIU J, CHEN Z, LI G, ZHENG Z, QIU S, LUO J, YE C, ZHU S, ZHENG J, ZHANG N, LI Y, HE J, LI J, LI S, ZHONG N; MEDICAL TREATMENT EXPERT GROUP FOR COVID-19: Longitudinal hematologic and immunologic variations associated with the progression of COVID-19 patients in China. J Allergy Clin Immunol 146: 89-100, 2020. https://doi.org/10.1016/j.jaci.2020.05.003

CHEN Y, GUO Y, PAN Y, ZHAO ZJ: Structure analysis of the receptor binding of 2019-nCoV. Biochem Biophys Res Commun 525: 135-140, 2020. https://doi.org/10.1016/j.bbrc.2020.02.071

CHUMAKOV K, BENN CS, AABY P, KOTTILIL S, GALLO R: Can existing live vaccines prevent COVID-19? Science 368: 1187-1188, 2020. https://doi.org/10.1126/science.abc4262

DE SMET D, DE SMET K, HERROELEN P, GRYSPEERDT S, MARTENS GA: Vitamin D deficiency as risk factor for severe COVID-19: a convergence of two pandemics. (Preprint) medRxiv 2020: 20079376, 2020. https://doi.org/10.1101/2020.05.01.20079376

DIAO B, WANG C, TAN Y, CHEN X, LIU Y, NING L, CHEN L, LIU M, LIU Y, WANG G, YUAN Z, FENG Z, ZHANG Y, WU Y, CHEN Y: Reduction and functional exhaustion of $\mathrm{T}$ cells in patients with Coronavirus Disease 2019 (COVID-19). Front Immunol 11: 827, 2020. https://doi.org/10.3389/fimmu.2020.00827

DONG Y, MO X, HU Y, QI X, JIANG F, JIANG Z, TONG S: Epidemiological characteristics of 2143 pediatric patientswith 2019 coronavirus disease in China. Pediatrics 2020. https://doi.org/10.1542/peds.2020-0702

FRANCESCHI C, GARAGNANI P, PARINI P, GIULIANI C, SANTORO A: Inflammaging: a new immune-metabolic view point for age-related diseases. Nat Rev Endocrinol 14: 576-590, 2018. https://doi.org/10.1038/s41574-018$\underline{0059-4}$

FRANKLIN R, YOUNG A, NEUMANN B, REYAHI A, JOANNIDES A, MODIS Y, FRANKLIN JRM: Homologous protein domains in SARS-CoV-2 and measles, mumps and rubella viruses: preliminary evidence that MMR vaccine might provide protection against COVID-19. medRxiv 2020. https://doi.org/10.1101/2020.04.10.20053207

FELSENSTEIN S, HERBERT JA, MCNAMARA PS, HEDRICH CM: COVID-19: Immunology and treatment options. Clin Immunol 215: 108448, 2020. https://doi.org/10.1016/j.clim.2020.108448

FREEMAN T, SWARTZ T: Targeting the NLRP3 Inflammasome in Severe COVID-19. Front Immunol 11: 1518, 2020. https://doi.org/10.3389/fimmu.2020.01518

GALANTI M, SHAMAN J: Direct observation of repeated infections with endemic coronaviruses: J Infect Dis 223: 409-415, 2021. https://doi.org/10.1093/infdis/jiaa392

GALLO MARIN B, AGHAGOLI G, LAVINE K, YANG L, SIFF EJ, CHIANG SS, SALAZAR-MATHER TP, DUMENCO L, SAVARIA MC, AUNG SN, FLANIGAN T, MICHELOW IC: Predictors of COVID-19 severity: A literature review. Rev Med Virol 31: 1-10, 2021. https://doi.org/10.1002/rmv.2146 
GATTORNO M, FEDERICI S, PELAGATTI MA, CAORSI R, BRISCA G, MALATTIA C, MARTINI A: Diagnosis and management of autoinflammatory diseases in childhood. J Clin Immunol 28 (Suppl 1): 73-83, 2008. https://doi.org/10.1007/s10875-008-9178-3

GIAMARELLOS-BOURBOULIS EJ, TSILIKA M, MOORLAG S, ANTONAKOS N, KOTSAKI A, DOMINGUEZANDRES J, KYRIAZOPOULOU E, GKAVOGIANNI T, ADAMI ME, DAMORAKI G, KOUFARGYRIS P, KARAGEORGOS A, BOLANOU A, KOENEN H, VAN CREVEL R, DROGGITI DI, RENIERIS G, PAPADOPOULOS A, NETEA MG: Activate: randomized clinical trial of BCG vaccination against infection in the elderly. Cell 183: 315-323, 2020. https://doi.org/10.1016/j.cell.2020.08.051

HARWEY WT, CARABELLI AM, JACKSON B, GUPTA RK, THOMSON EC, HARRISON EM, LUDDEN C, REEVE R, RAMBAUT A: SARS-CoV-2 variants, spike mutations and immune escape. Nat Rev Microbiol 19: 409-424, 2021. https://doi.org/10.1038/s41579-021-00573-0

HENRY BM, LIPPI G, PLEBANI M: Laboratory abnormalities in children with novel coronavirus disease 2019. Clin Chem Lab Med 58: 1135-1138, 2020. https://doi.org/10.1515/cclm-2020-0272

HOFFMANN M, KLEINE-WEBER H, SCHROEDER S, KRUGER N, HERRLER T, ERICHSEN S, SCHIERGENS TS, HERRLER G, WU NH, NITSCHE A, MULLER MA, DROSTEN C, POHLMANN S: SARS-CoV-2 cell entry depends on ACE2 and TMPRSS2 and is blocked by a clinically proven protease inhibitor. Cell 181: 271-280.e8, 2020. https://doi.org/10.1016/j.cell.2020.02.052

HOLICK MF: Vitamin D deficiency. N Engl J Med 357: 266-281, 2007. https://doi.org/10.1056/NEJMra070553

HUANG G, KOVALIC A J, GRABER CHJ: Prognostic value of leukocytosis and lymphopenia for severe coronavirus disease. Emerg Infect Dis 26: 1839-1841, 2020. https://doi.org/10.3201/eid2608.201160

IBRAHIM IM, ABDELMALEK DH, ELFIKY AA: GRP78: a cell's response to stress. Life Sci 226: 156-163, 2019. https://doi.org/10.1016/j.1fs.2019.04.022

IBRAHIM IM, ABDELMALEK DH, ELSHAHAT ME, ELFIKY AA: COVID-19 spike-host cell receptor GRP78 binding site prediction. J Infect 80: 554-562, 2020. https://doi.org/10.1016/j.jinf.2020.02.026

JESENAK M, BRNDIAROVA M, URBANCIKOVA I, RENNEROVA Z, VOJTKOVA J, BOBCAKOVA A: Immune parameters and COVID-19 infection - associations with clinical severity and disease prognosis. Front Cell Infect Microbiol 10: 364, 2020. https://doi.org/10.3389/fcimb.2020.00364

JESENAK M, RENNEROVA Z, BANOVCIN P: Praktický pohl'ad na vývoj imunitného systému v detskom veku. Pediatria (Bratisl) 7: 141-149, 2012.

JIANG M, GUO I, LUO Q, HUANG Z, ZHAO R, LIU S, LE A, LI J, WAN L: T cell subset counts in peripheral blood can be used as discriminatory biomarkers for diagnosis and severity prediction of COVID-19. J Infect Dis 222: 198-202, 2020. https://doi.org/10.1093/infdis/jiaa252

KINDLER E, THIEL V, WEBER F: Interaction of SARS and MERS coronaviruses with the antiviral interferon response. Adv Virus Res 96: 219-243, 2016. https://doi.org/10.1016/bs.aivir.2016.08.006

KLEINNIJENHUIS J, VAN CREVEL R, NETEA MG: Trained immunity: consequences for the heterologous effects of BCG vaccination. Trans R Soc Trop Med Hyg 109: 29-35, 2015. https://doi.org/10.1093/trstmh/tru168

KOPECKY-BROMBERG SA, MARTINEZ-SOBRIDO L, FRIEMAN M, BARIC RA, PALESE P: Severe acute respiratory syndrome coronavirus open readingframe (ORF) 3b, ORF 6, and nucleocapsid proteins function as interferon antagonists. J Virol 81: 548-557, 2007. https://doi.org/10.1128/JVI.01782-06

KUMAR H, KAWAI T, AKIRA S: Pathogen recognition in the innate immune response. Biochem J 420: 1-16, 2009. https://doi.org/10.1042/BJ20090272

LEUNG JM, YANG CX, TAM A, SHAIPANICH T, HACKETT TL, SINGHERA GK, DORSCHEID DR, SIN DD: ACE-2 expression in the small airway epithelia of smokers and COPD patients: implications for COVID-19. Eur Respir J 55: 2000688, 2020. https://doi.org/10.1183/13993003.00688-2020

LOSCOCCO GG: Secondary hemophagocytic lymphohistiocytosis, HScore and COVID-19. Int J Hematol 112: 125-126, 2020. https://doi.org/10.1007/s12185-020-02895-w

LU X, PAN J, TAO J, GUO D: SARS-CoV nucleocapsid protein antagonizes IFN-beta response by targeting initial step of IFN-beta induction pathway, and its C-terminal region is critical for the antagonism. Virus Genes 42: 37-45, 2011. https://doi.org/10.1007/s11262-010-0544-X 
MAGHBOOLI Z, SAHRAIAN MA, EBRAHIMI M, PAZOKI M, KAFAN S, TABRIZ HM, HADADI A, MONTAZERI M, NASIRI M, SHIRVANI A, HOLICK MF: Vitamin D sufficiency, a serum 25-hydroxyvitamin D at least $30 \mathrm{ng} / \mathrm{mL}$ reduced risk for adverse clinical outcomes in patients with COVID-19 infection. PLoS One 15: e023979, 2020. https://doi.org/10.1371/journal.pone.0239799

MACHHI J, HERSKOVITZ J, SENAN AM, DUTTA D, NATH B, OLEYNIKOV MD, BLOMBERG WR, MEIGS DD, HASAN M, PATEL M, KLINE P, CHANG RC, CHANG L, GENDELMAN HE, KEVADIYA BD: The natural history, pathobiology, and clinical manifestations of SARS-CoV-2 infections. J Neuroimmune Pharmacol 15: 359-386, 2020. https://doi.org/10.1007/s11481-020-09944-5

MEHTA P, MCAULEY DF, BROWN M, SANCHEZ E, TATTERSALL RS, MANSON JJ; HLH ACROSS SPECIALITY COLLABORATION, UK: COVID-19: consider cytokine storm syndromes and immunosuppression. Lancet 395: 1033-1034, 2020. https://doi.org/10.1016/S0140-6736(20)30628-0

MERAD M, MARTIN JC: Pathological inflammation in patients with COVID-19: a key role for monocytes and macrophages. Nat Rev Immunol 20: 355-362, 2020. https://doi.org/10.1038/s41577-020-0331-4

MOORLAG SJCFM, ARTS RJW, VAN CREVEL R, NETEA MG: Non-specific effects of BCG vaccine on viral infections. Clin Microbiol Infect 25: 1473-1478, 2019. https://doi.org/10.1016/j.cmi.2019.04.020

MOSEKILDE L: Vitamin D and the elderly. Clin Endocrinol 62: 265-281, 2005. https://doi.org/10.1111/j.13652265.2005.02226.x

MURAMATSU T, MIYAUCHI T: Basigin (CD147): a multifunctional transmembrane protein involved in reproduction, neural function, inflammation and tumor invasion. Histol Histopathol 18: 981-987, 2003. https://doi.org/10.14670/HH-18.981

NETEA MG, DOMINGUEZ-ANDRES J, BARREIRO LB, CHAVAKIS T, DIVANGAHI M, FUCHS E, JOOSTEN LAB, VAM DER MEER JWM, MHLANGA MM, MULDER WJM, RIKSEN NP, SCHLITZER A, SCHULTZE JL, STABELL BENN C, SUN JC, XAVIER RJ, LATZ E: Defining trained immunity and its role in health and disease. Nat Rev Immunol 20: 375-388, 2020. https://doi.org/10.1038/s41577-020-0285-6

O'DRISCOLL M, RIBEIRO DOS SANTOS G, WANG L, CUMMINGS DAT, AZMAN AS, PAIREAU J, FONTANET A, CAUCHEMEZ S, SALJE H: Age-specific mortality and immunity patterns of SARS-CoV-2. Nature 590: 140-145, 2021. https://doi.org/10.1038/s41586-020-2918-0

PANAGIOTOU G, TEE SA, IHSAN Y, ATHAR W, MARCHITELLI G, KELLY D, BOOT CS, STOCK N, MACFARLANE J, MARTINEAU AR, BURNS G, QUINTON R: Low serum 25-hydroxyvitamin D (25[OH]D) levels in patients hospitalized with COVID-19 are associated with greater disease severity. Clin Endocrinol 93: 508511, 2020. https://doi.org/10.1111/cen.14276

PIERCE CA, PRESTON-HURLBURT P, DAI Y, ASCHNER CB, CHESHENKO N, GALEN B, GARFORTH SJ, HERRERA NG, JANGRA RK, MORANO NC, ORNER E, SY S, CHANDRAN K, DZIURA J, ALMO SC, RING A, KELLER MJ, HEROLD KC, HEROLD BC: Immune responses to SARSCoV-2 infection in hospitalized pediatric and adult patients. Sci Transl Med 12: eabd5487, 2020. https://doi.org/10.1126/scitranslmed.abd5487

PROMPETCHARA E, KETLOY C, PALAGA T: Immune responses in COVID-19 and potential vaccines: Lessons learned from SARS and MERS epidemic. Asian Pac J Allergy Immunol 38: 1-9, 2020. https://doi.org/10.12932/AP-200220-0772

RABI A, AL ZOUBI MS, KASASBEH GA, SALAMEH DM, AL-NASSER AD: SARS-CoV-2 and Coronavirus disease 2019: what we know so far. Pathogens 9: 231, 2020. https://doi.org/10.3390/pathogens9030231

RIBERO SA M, JOUVENET N, DREUX M, NISOLE S: Interplay between SARS-CoV-2 and the type I interferon response. PLoS Pathog 16: e1008737, 2020. https://doi.org/10.1371/journal.ppat.1008737

RUAN Q, YANG K, WANG W, JIANG L, SONG J: Clinical predictors of mortality due to COVID-19 based on ananalysis of data of 150 patients from Wuhan, China. Intensive Care Med 46: 846-848, 2020. https://doi.org/10.1007/s00134-020-05991-x

SALAMANNA F, MAGLIO M, LANDINI MP, FINI M: Body localization of ACE-2: On the trail of the keyhole of SARS-CoV-2. Front Med (Lausanne) 7: 594495, 2020. https://doi.org/10.3389/fmed.2020.594495

SHARIFI N, RYAN CJ EDITORIAL: Androgen hazards with COVID-19. Endocr Relat Cancer 27: E1-E3, 2020. https://doi.org/10.1530/ERC-20-0133 
SHI CS, NABAR NR, HUANG NN, KEHRL JH: SARS-coronavirus open reading frame-8b triggers intracellular stress pathways and activates NLRP3 inflammasomes. Cell Death Discov 5: 101, 2019. https://doi.org/10.1038/s41420-019-0181-7

SHOKRI S, MAHMOUNDVAND S, TAHEKRANI R, FARSHADPOUR F: Modulation of the immune response by Middle East respiratory syndrome coronavirus. J Cell Physiol 234: 2143-2151, 2019. https://doi.org/10.1002/jcp.27155

SCHNEIDER WM, CHEVILLOTTE M, RICE C: Interferon-stimulated genes: a complex web of host defenses. Annu Rev Immunol 32: 513-545, 2014. https://doi.org/10.1146/annurev-immunol-032713-120231

SCHULER BA, HABERMANN AC, PLOSA EJ, TAYLOR CJ, JETTER C, KAPP ME, BENJAMIN JT, GULLEMAN P, NICHOLS DS, BRAUNSTEIN LZ, HACKETT A, KOVAL M, GUTTENTAG SH, BLACKWELL TS; VANDERBILT COVID-19 CONSORTIUM COHORT, WEBBER SA, BANOVICH NE, KROPSKI JA, SUCRE JMS; HCA LUNG BIOLOGICAL NETWORK: Age-determined expression of priming protease TMPRSS2 and localization of SARS-CoV-2 infection in the lung epithelium. J Clin Invest 131: 2021. https://doi.org/10.1101/2020.05.22.111187

SIMON AK, HOLLANDER GA, MCMICHAEL A: Evolution of the immune system in humans from infancy to old age. Proc Biol Sci 282: 20143085, 2015. https://doi.org/10.1098/rspb.2014.3085

SINAEI R, PEZESHKI S, PARVARESH S, SINAEI R: Why COVID-19 is less frequent and severe in children: a narrative review. World J Pediatr 17: 10-20, 2021. https://doi.org/10.1007/s12519-020-00392-y

SONG JW, ZHANG C, FAN X, MENG FP, XU Z, XIA P, CAO WJ, YANG T, DAI XP, WANG SY, XU RN, JIANG TJ, LI WG, ZHANG DW, ZHAO P, SHI M, AGRATI C, IPPOLITO G, MAEURER M, ZUMLA A, WANG FS, ZHANG JY: Immunological and inflammatory profiles in mild and severe cases of COVID-19. Nat Commun 11: 3410, 2020. https://doi.org/10.1038/s41467-020-17240-2

TAFFAREL P, JORRO BARÓN F, RODRÍGUEZ AP, WIDMER J, MEREGALLIA C: Multisystem inflammatory syndrome in children related to COVID-19: An update regarding the presentation of two critically ill patients. Arch Argent Pediatr 119: e26-e35, 2021. https://doi.org/10.5546/aap.2021.eng.e26

TAN L, WANG Q, ZHANG D, DING J, HUANG Q, TANG YQ, WANG Q, MIAO H: Lymphopenia predicts disease severity of COVID-19: a descriptive and predictive study. Signal Transduct Target Ther 5: 33, 2020. https://doi.org/10.1038/s41392-020-0148-4

TERPOS E, NTANASIS-STATHOPOULOS I, ELALAMY I, KASTRITIS E, SERGENTANIS TN, POLITOU M, PSALTOPOULOU T, GEROTZIAFAS G, DIMOPOULOS MA: Hematological findings and complications of COVID-19. Am J Hematol 95: 834-847, 2020. https://doi.org/10.1002/ajh.25829

TSABOURI S, MAKIS A, KOSMERI C, SIOMOU E: Risk factors for severity in children with coronavirus disease 2019: A comprehensive literature review. Pediatr Clin North Am 68: 321-338, 2021. https://doi.org/10.1016/j.pcl.2020.07.014

WALLS AC, PARK YJ, TORTORICI MA, WALL A, MCGUIRE AT, VEESLER A: Structure, function, and antigenicity of the SARS-CoV-2. Cell 181: 281-292, 2020. https://doi.org/10.1016/j.cell.2020.02.058

WAMBIER CG, GOREN A, VAÑO-GALVÁN S, RAMOS PM, OSSIMETHA A, NAU G, HERRERA S, MCCOY J: Androgen sensitivity gateway to COVID-19 disease severity. Drug Dev Res 81: 771-776, 2020. https://doi.org/10.1002/ddr.21688

WANG A, CHIOU J, POIRION OB, BUCHANAN J, VALDEZ MJ, VERHEYDEN JM, HOU X, KUDTARKAR P, NARENDRA S, NEWSOME JM, GUO M, FADDAH DA, ZHANG K, YOUNG RE, BARR J, SAJTI E, MISRA R, HUYCK H, ROGERS L, POOLE C, ET AL.: Single-cell multiomic profiling of human lungs reveals cell-type-specific and age-dynamic control of SARS-CoV2 host genes. Elife 9: e62522, 2020. https://doi.org/10.7554/eLife.62522

WANG D, HU B, HU C, ZHU F, LIU X, ZHANG J, WANG B, XIANG H, CHENG Z, XIONG Y, ZHAO Y, LI Y, WANG X, PENG Z: Clinical characteristics of 138 hospitalized patients with 2019 novel coronavirus-infected pneumonia in Wuhan, China. JAMA 323: 1061-1069, 2020. https://doi.org/10.1001/jama.2020.1585

WANG F, HOU H, LUO Y, TANG G, WU S, HUANG M, LIU W, ZHU Y, LIN Q, MAO L, FANG M, ZHANG H, SUN Z: The laboratory tests and host immunity of COVID-19 patients with different severity of illness. JCI Insight 5: e137799, 2020. https://doi.org/10.1172/jci.insight.137799 
WANG K, CHEN W, ZHANG Z, YONGQJANG D, JIAN-QI L, PENG D, DING W, YANG Z, XIU-XUAN S, LI G, XU Y, LEI H, LEI Z, ZHIWEI Y, JIE-JIE G, RUO CH, HAI Z, BIN W, YU-MENG Z, GANG N, ET AL.: CD147-spike proteinis a novel route for SARS-CoV-2 infection to host cells. Sig Transduct Target Ther 5: 283, 2020. https://doi.org/10.1038/s41392-020-00426-X

WEISBERG SP, CONNORS TJ, ZHU Y, BALDWIN MR, LIN WH, WONTAKAL S, SZABO PA, WELLS SB, DOGRA P, GRAY J, IDZIKOWSKI E, STELITANO D, BOVIER FT, DAVIS-PORADA J, MATSUMOTO R, POON MML, CHAIT M, MATHIEU C, HORVAT B, DECIMO D, ET AL.: Distinct antibody responses to SARS-CoV-2 in children and adults across the COVID-19 clinical spectrum. Nat Immunol 22: 25-31, 2021. https://doi.org/10.1038/s41590-020-00826-9

XU Z, SHI L, WANG Y, ZHANG J, HUANG L, ZHANG C, LIU S, ZHAO P, LIU H, ZHU L, TAI Y, BAI C, GAO T, SONG J, XIA P, DONG J, ZHAO J, WANG FS: Pathological findings of COVID-19 associated with acute respiratory distress syndrome. Lancet Respir Med 8: 420-422, 2020. https://doi.org/10.1016/S2213-2600(20)30076$\underline{\mathrm{X}}$

YANG CS, SHIN DM, JO EK: The role of NLR-related protein 3 inflammasome in host defense and inflammatory diseases. Int Neurourol 16: 2-12, 2012. https://doi.org/10.5213/inj.2012.16.1.2

YGBERG S, NILSSON A: The developing immune system - from foetus to toddler. Acta Paediatr 101: 120-127, 2012. https://doi.org/10.1111/j.1651-2227.2011.02494.x

YOSHIKAWA T, HILL TE, YOSHIKAWA N, POPOV VL, GALINDO CL, GARNER HR, PETERS CJ, TSENG CT: Dynamic innate immune responses of human bronchial epithelial cells to severe acute respiratory syndromeassociated coronavirus infection. PLoS One 5: e8729, 2010. https://doi.org/10.1371/journal.pone.0008729

ZHOU S, ZHOU H, WALIAN PJ, JAP BK: CD147 is a regulatory subunit of the gamma-secretase complex in Alzheimer's disease amyloid beta-peptide production. Proc Natl Acad Sci U S A 102: 7499-7504, 2005. https://doi.org/10.1073/pnas.0502768102

ZUO Y, YALAVARTHI S, SHI H, GOCKMAN K, ZUO M, MADISON JA, BLAIR C, WEBER A, BARNES BJ, EGEBLAD M, WOODS RJ, KANTHI Y, KNIGHT JS: Neutrophil extracellular traps in COVID-19. JCI Insight 5: e138999, 2020. https://doi.org/10.1172/jci.insight.138999 